Emma Lightfoot, Magdalena Naum, Villu Kadakas and Erki Russow

\title{
THE INFLUENCE OF SOCIAL STATUS AND ETHNICITY ON DIET IN MEDIAEVAL TALLINN AS SEEN THROUGH STABLE ISOTOPE ANALYSIS
}

Food encodes social and cultural values and has an important role to play in defining identities. In mixed populations, diet can be used to distinguish between 'us' and 'them'. This study investigates the extent to which the inhabitants of mediaeval Tallinn, an important trading centre, used food to maintain distinct identities. Human skeletal material was selected from four mediaeval cemeteries in Tallinn, chosen to represent different groups within Tallinn's society, likely including foreign merchants, foreign monks, urban Estonians and low-status Estonians, and from a nearby rural site, Kaberla, for comparative purposes. The individuals were investigated using carbon, nitrogen and oxygen stable isotope analysis. The results indicate that while all analysed individuals consumed diets based on $\mathrm{C}_{3}$ plants and animals consuming $\mathrm{C}_{3}$ plants, some individuals also consumed small amounts of $\mathrm{C}_{4}$ plants (likely millet) or seafood. $\mathrm{C}_{4}$ plants were consumed by the urban residents buried at the Church of the Holy Spirit and one or two individuals from Sulevimägi. It is thought that millet was an imported food consumed by the middle class. Marine foods were consumed by the individuals at St Catherine's Church. These individuals were also identified as migrants and were likely either monks or foreign merchants. The results suggest that in some cases the people of Tallinn did use food as a means of maintaining social statuses and potentially ethnicities. Only one individual (LTL06) was identified as having had a significant change in diet during life, with the inclusion of marine foods in adulthood. This may indicate that this individual attained or aspired to higher social status during life and adhered to Christian dietary customs.

Emma Lightfoot, McDonald Institute for Archaeological Research, University of Cambridge, Downing Street, Cambridge, CB2 3ER, United Kingdom; elf12@cam.ac.uk

Magdalena Naum, Faculty of Humanities, University of Oulu, P.O. Box 1000, 90014 Oulu, Finland; magdalena.naum@oulu.fi

Villu Kadakas, Institute of History, Tallinn University, 6 Rüütli St., 10130 Tallinn, Estonia; villu.kadakas@tlu.ee

Erki Russow, Institute of History, Tallinn University, 6 Rüütli St., 10130 Tallinn, Estonia; erki.russow@tlu.ee 


\section{Introduction}

Diet has an important role to play in encoding social and cultural values, with food often used to demarcate 'us' and 'them' (Douglas 1972; Harris 1985). When different social and ethnic groups live together in an urban setting, food can be one way to maintain distinct group identities. On the other hand, diet can also be a means to bring disparate peoples together - immigrants can alter their diet to that of the local people in order to assimilate into the local population (or due to resource availability), while sometimes relatively small numbers of migrants may cause large-scale social and cultural change, particularly if they attain high social status (Anthony 1997). Mediaeval Tallinn played an important role in international trade and as such was home to people from across northern Europe. Here, we aim to consider the diet and migratory status of various individuals who were buried in Tallinn to investigate how diet was used to construct identity.

Throughout the period under study, Tallinn (Reval in German; Fig. 1) was a relatively large Hanseatic town, with approximately 5000 inhabitants in the late 14th century and about 6700 in the first half of the 16th century (Johansen \& von zur Mühlen 1973). About half of the town's population were of Estonian origin, a third were German and the rest were mostly Swedes and Finns with a few Russians (Johansen \& von zur Mühlen 1973; Selart 2009b; Naum 2014). Throughout the period under study, new immigrants arrived in Tallinn from Germany, Scandinavia, coastal Finland and the Estonian countryside, replacing the population lost to urban epidemics (Johansen \& von zur Mühlen 1973). The German population represented the elite, and the written documents indicated a sharp legal and social divide between 'German' (Deutsch) and 'un-German' (Undeutsch), that is mostly the Estonian population. Different ethnic communities living in the lower town of Tallinn interacted with each other despite social, religious and cultural differences. These interactions had transformative albeit polysemous effects. On the one hand, they inspired merging and borrowing in the sphere of material culture and certain degrees of assimilation and crossing of ethnic boundaries. On the other hand, they fuelled cultural conservatism and fostered processes of distinction, developing and defining group boundaries, collective and individual identities that were articulated in material choices and specific practices (Johansen \& von zur Mühlen 1973, 405-432; Naum 2014). While there are some documented cases of Estonians 'becoming' German (through intermarriage and social manoeuvring) and impoverished Germans falling in status and unable to document their ancestry becoming classified as Estonians, in legal and social terms, the historical sources give an impression of a deep divide between the two communities (Johansen \& von zur Mühlen 1973).

The aim of the study is to acquire a better understanding of the relationship between diet and the social background of urban residents and to interrogate the assumption made in historical sources that the cultural habitus, lifestyle and social status of Tallinn's residents had a major influence on the consumed food. Stable isotope analyses were carried out on the skeletal material from 14 humans and 


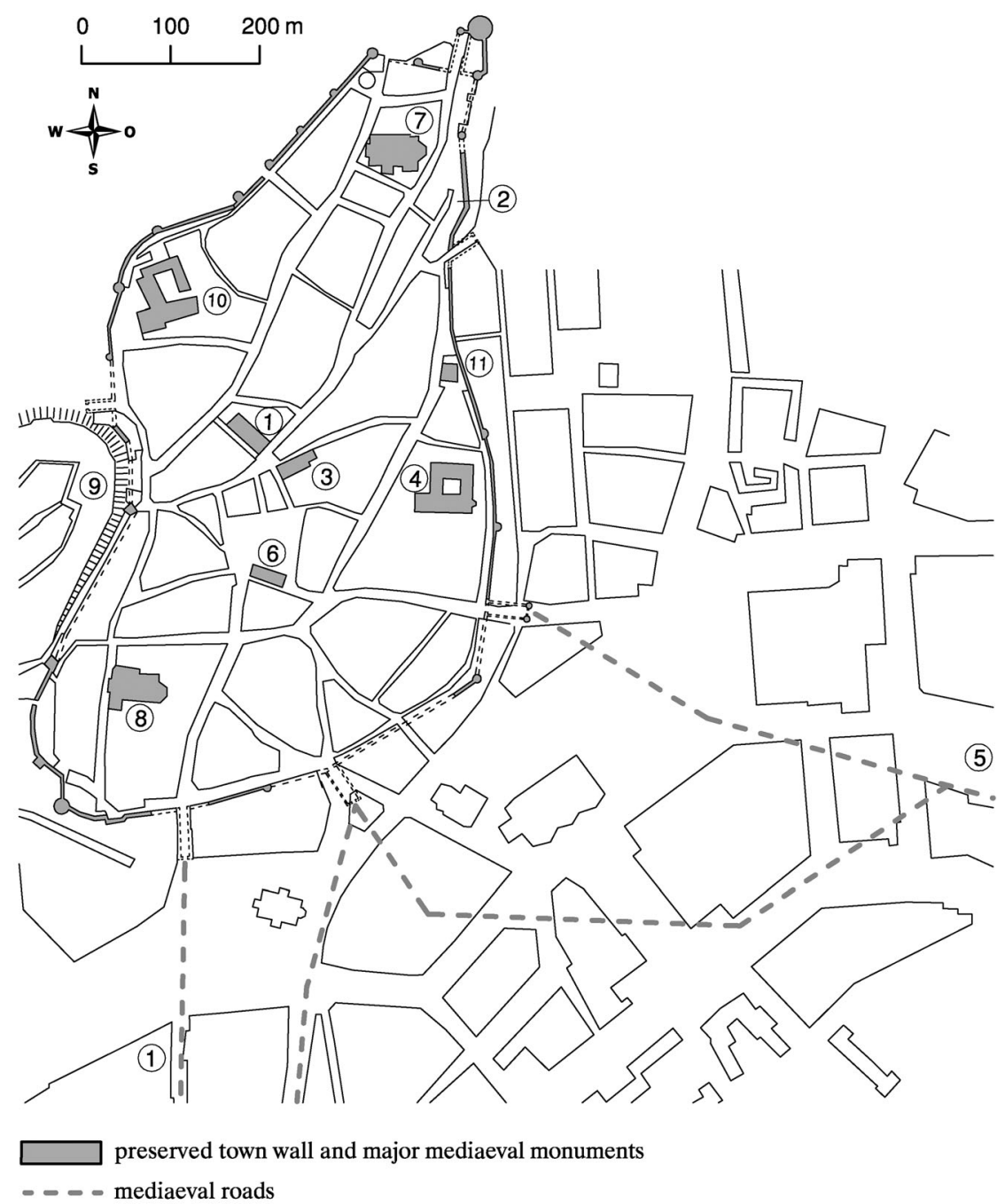

Fig. 1. Plan of the Old Town (lower town part) and present town centre. Excavation sites and major mediaeval monuments. 1 Site of former St Barbara cemetery, 2 site of former Russian Orthodox church and cemetery in Sulevimägi 4/6, 3 church of the Holy Spirit, 4 ruins of St Catherine's Church and the Dominican Friary, 5 excavations in Tartu Rd 1, 6 Town Hall, 7 St Olaf's Church, 8 St Nicholas' Church, 9 Toompea Hill (castle area), 10 St Michael's Cistercian nunnery, 11 St Nicholas' Russian Orthodox church. Drawing by Villu Kadakas.

8 animals from sites chosen from within the city to represent different groups within Tallinn's society (likely including foreign merchants, foreign monks, urban Estonians and low-status Estonians) and compared to a nearby village, Kaberla (Fig. 2). While more individuals were excavated from the analysed sites (see below), unfortunately only this small sample was available for analysis as very few individuals were preserved in the museum collections. Carbon, nitrogen and 


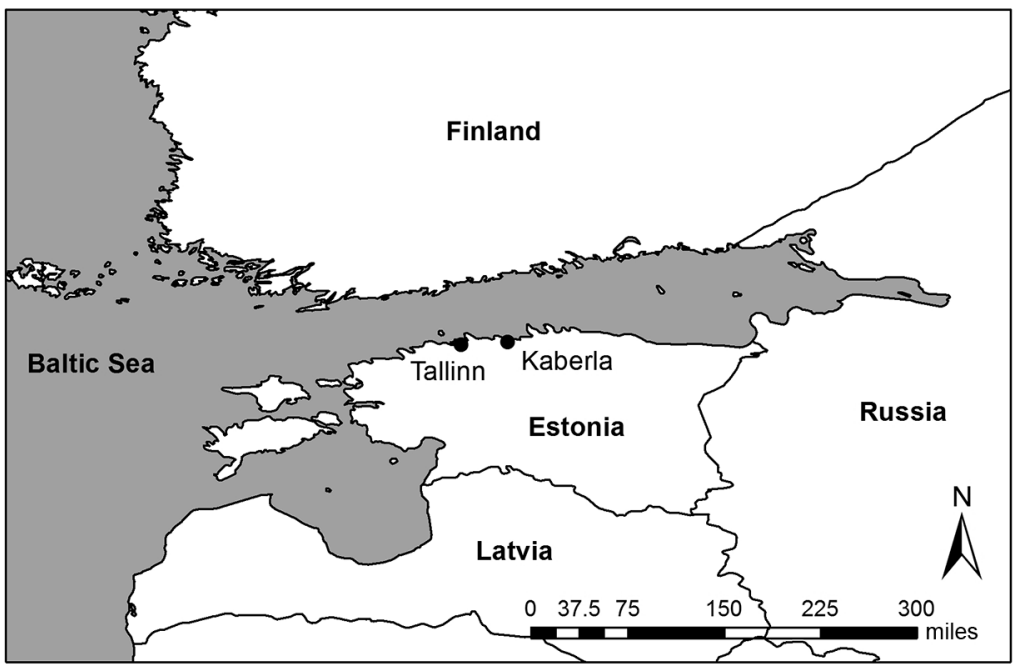

Fig. 2. Map of location of Tallinn and Kaberla.

oxygen isotope analyses were conducted on bone collagen, tooth dentine and tooth enamel from human samples, and on tooth dentine and tooth enamel from the animal samples. In this way, we are able to directly study the diet of the individuals, to consider their places of birth and life histories, and to compare burial populations from within the town and from a nearby rural context.

\section{Archaeological and historical evidence for diet in Tallinn}

Archaeological analyses of plant and animal remains from mediaeval Tallinn are rather limited but we can make some general inferences from the information available. The most common plants identified in the late mediaeval town and its suburbs are barley, turnip, wild berries and hazelnuts (Sillasoo \& Hiie 2007). Samples taken from a 15th-16th century latrine at Sulevimägi also contained remains of common millet, oats, buckwheat, pea, figs and cultivated black currants, while wheat, sour cherries, pears and grapes were identified in excavations of sites associated with German residents (Sillasoo \& Hiie 2007). There are relatively copious sources describing food, cookery and food presentation at feasts and special gatherings, which allows one to speculate what might have been considered as 'standard' festive foods and exclusive commodities consumed only sporadically among the middle and upper classes in the town (Mänd 2005). Cheese, locally brewed beer, dried and salted fish, bread, common vegetables and legumes were the daily staples. Varieties of fresh meats and fish, ham, imported wine, nuts and fruits along with spices were considered standard festive foods throughout the late Middle Ages and Renaissance, while candied fruits, sugar, almond purée and 
game were rarely tasted even by the upper echelons of the Tallinn's burghership (Mänd 2005).

Differences in the lifestyle and diet between Estonian and German residents of the town are implied in the historical sources and hinted at in archaeological material. Late mediaeval town books differentiated, for example, between several types of expensive and cheap baked goods, which were probably consumed by the German and the un-German population, respectively (Johansen \& von zur Mühlen 1973; Mänd 2005). There are also clear differences in the pottery assemblages with German families using high quantities of imported tableware compared to locally produced earthenware and imported blue-grey ware. This ceramics' ratio is reversed in the cases of sites associated with non-German settlers (Naum 2014).

\section{Site background and samples}

\section{Sulevimägi Cemetery}

Sulevimägi Cemetery was located in the Old Town of Tallinn. Based on a few written sources from the 13th and 14th century, 'Old Russian church' and a 'Russian cemetery', it had been concluded that the Russian Orthodox church together with a trading post of Russian traders, originally from Novgorod, was situated somewhere in this area. It has been speculated that the trading post of Novgorod merchants was already established in Tallinn in the 12th or even 11th century, but this hypothesis, which has often been cited as a fact, lacks both written and material evidence (Johansen 1951, 66-87; Tiik 1957, 382 f.; Kleinenberg 1962, 242; see also Selart 2009a, 280). The buildings and graveyard fell out of use at the beginning of the 15th century (Tiik 1957, 385; Kleinenberg 1962, 242; Johansen 1965, 98; Selart 2009a, 281). Although no building remains could be associated with the church or the trading post during the rescue excavations in 2003, twelve burials were uncovered (Kadakas \& Nilov 2004, 170). These individuals were buried with their heads towards the west and without grave goods and can therefore be considered Christian burials. It is likely that they are associated with the Novgorod merchant diaspora of the 13th-14th century. However, as suggested by Johansen, they might also relate to the period before the establishment of the town, to a trading post of the 12th century, and belong to the converted locals (Johansen 1951, 66-88). Four individuals were sampled.

\section{St Catherine's Church}

St Catherine's was the church of a Dominican Friary which existed from the middle of the 13th century until the Reformation. In 1524 the Friary was dissolved and the building given to the ethnic Estonian Lutheran congregation (Vaga 1965, 162 ff.; Tool-Marran 1971, 44 ff.; Raam 1975, 59; see also Mäeväli 1986, 94 ff.). In 1531 the church burnt down and was not rebuilt (Tool-Marran 1971, 32 f.; Mäeväli 1986, 94 ff.; Kala 2013, 374 ff.). 
Two test pits dug in the nave in 2005 revealed three well-preserved burials, two of which were sampled (Kadakas 2006). If the individuals pre-date the Reformation, they may represent monks. It was common practice for Dominican monks to move from one friary to another, in the case of Tallinn mostly from Scandinavia and various parts of Germany (Kala 2006b, 184 f.; 2013, 120). It is not known how common it was to bury lay people in the church, but there is evidence for the burial of foreigners in the church (Tool-Marran 1971, 130). It can be concluded that it is entirely possible that the two sampled burials represent people who were born abroad.

\section{Church of the Holy Spirit}

The Church of the Holy Spirit (Pühavaimu kirik) is located in the centre of the Old Town of Tallinn. In the Middle Ages it operated in conjunction with an almshouse. It was first mentioned in sources in 1316, but was probably established by the 13th century (Nottbeck \& Neumann 1899, 108; Tiik 1957, 305 f.; Lumiste 1971, 5 f.; Mäeväli 1986; Kala 2006a, 157). Following the destruction of the Dominican Church in 1531 (see above), the building was given to an Estonian Lutheran congregation.

The cemetery is first mentioned in documents dating to 1390 (Lumiste 1971, 5). It is difficult to estimate when the cemetery fell out of use, but burials must have ceased by 1771-1772, when burial inside the Old Town was forbidden (Polnoye 1830, 409, 500, 691; Malve et al. 2014, 121). It is likely, however, that spatial constraints meant that the cemetery fell out of use earlier than this, possibly even in the 17th or second half of the 16th century.

Some skeletons were discovered in 2004 next to the south-east wall of the church. No grave goods were found. It is not clear if these individuals date to pre- or post-Reformation (i.e. 1524). It is unlikely that large numbers of people were buried at the site, as the townspeople who had died in the almshouse would normally have belonged to one of the town's congregations and thus were probably buried elsewhere. Therefore, it is likely that people buried in the Holy Spirit churchyard were peasants from nearby rural areas. After the Reformation, the small churchyard might have been used by the few ethnic Estonian congregation members who lived inside the Old Town. In conclusion, in case of both periods, it seems more likely that the burials discovered in the churchyard were of relatively local origin, probably ethnic Estonian. Two individuals were sampled.

\section{St Barbara Cemetery}

St Barbara was a suburban cemetery that was used from the 14th to the 18th century and located $100 \mathrm{~m}$ south of the Old Town (Kangropool 1992). The samples were taken from an area of the cemetery that can be dated to the late 16th - early 
18th century. However, most of the individuals buried in this area are probably victims of a famine and diseases that struck the town in the early 17 th century (Müller 1891, 87 f.; Hansen 1894, 64). We can also infer that these individuals were probably recent, short-distance migrants to the town and would have eaten a rural peasant diet. If they were not victims of the famine, they were probably suburban residents who were mostly ethnic Estonians. In either case, these individuals may well represent low-status, Estonian individuals. Three individuals were sampled.

\section{Kaberla}

Kaberla is a large rural village cemetery, located ca $30 \mathrm{~km}$ east from the Old Town of Tallinn. It was excavated between 1955-1966, when 242 burials were found (Mark 1962). Of these, 56 are dated to the 12th-13th centuries, and the rest to the 14th-17th centuries. Burial numbers 114,183 and 223 were sampled. Burial number 114 was found with a fire-steel, an unidentified bone item and a Swedish copper coin from the 1660s (Selirand 1962, 141, 157). Burial number 183 is of later date (Selirand 1974, 75). The chronology of burial 223 is unclear. The three sampled burials are expected to be of local origin and to represent a rural Estonian diet.

\section{Tartu St., Tallinn}

The animal bones were taken from a suburban plot in Tallinn, located $0.5 \mathrm{~km}$ south-east of the Old Town and excavated in 2011-2012 (Kadakas et al. 2013; Russow et al. 2013). The samples were selected from secure 15th to 16th century layers. Four cows and four sheep or goats were sampled.

\section{Isotopic background}

\section{Carbon and nitrogen isotope analysis of bone collagen and dentine collagen}

Stable isotope analysis is a quantitative method for studying palaeodiet that provides dietary information at the level of an individual. As the human body is made from the food and drink consumed during the lifetime, the stable isotope ratios in body tissues reflect those of the dietary intake. When foods vary in their isotopic composition, individuals consuming these different diets can be identified on the basis of their skeletal chemistry. The protein, collagen, is extracted from bones and dentine for analysis. As body protein is primarily constructed from the dietary protein intake, the stable isotope ratios of collagen reflect mainly the protein portion of the diet (Ambrose \& Norr 1993; Tieszen \& Fagre 1993; Howland et al. 2003; Jim et al. 2006). Stable isotope ratios in adult bone collagen reflect diet over 
a period of years, as collagen has a slow rate of turnover (Hedges et al. 2007). The stable isotope ratios in dentine collagen reflect diet over the period of tooth formation, because dentine does not remodel during life. In this study, isotope analyses were conducted on human premolars, which form between the ages of 2 and 6 years (Smith 1991).

Carbon isotopic ratios can be used to distinguish either between marine and terrestrial diets (Schoeninger \& DeNiro 1984) or between diets based on two types of plants, $C_{3}$ and $C_{4}$ (Vogel \& van der Merwe 1977). Most staple plants are $\mathrm{C}_{3}$, including wheat, barley, rye and rice, while maize, sugar cane, millet and sorghum are $\mathrm{C}_{4}$. Nitrogen isotopic ratios provide an indication of the position of an animal in the food chain, as there is an increase in $\delta^{15} \mathrm{~N}$ of between 3 to 5\%o per trophic level (Bocherens \& Drucker 2003; Hedges \& Reynard 2007). Nitrogen isotopic ratios can also be used to distinguish between aquatic and terrestrial food chains, because both marine and freshwater ecosystems tend to have longer food chains than terrestrial ecosystems (Schoeninger \& DeNiro 1984).

\section{Carbon and oxygen isotope analysis of tooth enamel carbonate}

Carbon and oxygen isotopic ratios in tooth enamel carbonate reflect the food consumed and water drunk at the time of tooth enamel mineralization during childhood (Harrison \& Katzenberg 2003). As with carbon isotopes in collagen' carbon isotopes in tooth enamel can be used to distinguish between marine and terrestrial diets, or $\mathrm{C}_{3}$ and $\mathrm{C}_{4}$ plants. Unlike collagen which primarily reflects the protein component of the diet, carbon isotope values from enamel reflect the whole diet (Ambrose \& Norr 1993; Tieszen \& Fagre 1993).

Oxygen isotopic ratios in precipitation reflect the local climate and vary according to temperature and distance from the source of the water (Dansgaard 1964; Rozanski et al. 1992; 1993), but distinct isotopic patterning can also be related to a variety of temperature-related factors, such as latitude (Förstel \& Hützen 1983), altitude (Poage \& Chamberlain 2001), and season (Simpkins 1995). The oxygen isotopic ratios (expressed as $\delta^{18} \mathrm{O}$ ) of groundwater generally reflect the average isotopic composition of recent precipitation in the local source area. The oxygen isotope signal in tooth enamel carbonate is derived mainly from ingested water and thus reflects the local climate (Longinelli 1984; Luz \& Kolodny 1985). Individuals who consumed drinking water with an oxygen isotope value notably different from that of the local precipitation are identified as migrants, although it is important to note that individuals with oxygen isotope values consistent with that of the local water may have been migrants from areas where the consumed water was of similar isotopic composition. 


\section{Materials and methods \\ Carbon and nitrogen analysis of bone collagen and dentine}

Samples were taken from 14 humans and 6 animals. Full sample details are given in the Appendix. Bone and tooth dentine samples were taken from human ribs and premolars, respectively. Only dentine samples were available from the animals.

The laboratory method is based upon that in Richards and Hedges (1999). $\mathrm{Ca} 0.5 \mathrm{~g}$ of bone was sampled using a hand-held drill with a diamond cutting wheel. Samples were demineralized in $0.5 \mathrm{M}$ aq. $\mathrm{HCl}$ for up to 2 weeks at $4{ }^{\circ} \mathrm{C}$ and then gelatinized at $75^{\circ} \mathrm{C}$ for 48 hours in $\mathrm{pH} 3$ water. The 'collagen' was then lyophilized before weighing for isotopic analysis. Each sample was run in triplicate using a Costech elemental analyser coupled in continuous flow mode to a Finnigan isotope ratio mass spectrometer. Carbon and nitrogen isotopic ratios were measured on the delta scale in comparison to international standards, VPDB and AIR respectively, in units of 'permil' (Craig 1957; Mariotti 1983). Repeated measurements on international and in-house standards showed that the analytical error was $\pm 0.2 \%$ for both carbon and nitrogen.

Measured collagen is deemed to be of good quality if it fulfils the following criteria: an atomic C:N ratio of 2.9-3.6 (De Niro 1985); a 'collagen' yield of 1\% by mass; final carbon yields of 13\%; and final nitrogen yields of $4.8 \%$ (Ambrose 1990). All samples produced data deemed to be of good quality.

\section{Carbon and oxygen analysis of tooth enamel carbonate}

Tooth enamel carbonate samples were taken from the 14 human and 6 animal teeth sampled above for dentine, plus 2 ovicaprids that were not sampled for dentine. Full sample details are given in the Appendix.

Tooth enamel powder was taken using a hand held drill with a diamond drill attachment. The pretreatment method was based on that described in Balasse et al. (2002). $0.1 \mathrm{ml}$ of $2-3 \%$ aqueous sodium hypochlorite was added per $\mathrm{mg}$ of sample. The samples were then left for 24 hours at $4^{\circ} \mathrm{C}$ before being rinsed five times with distilled water to remove the sodium hypochlorite. $0.1 \mathrm{mg}$ of acetic acid was then added per mg of sample. The samples were then left for four hours at room temperature, before the acetic acid was removed and the samples rinsed. Samples were then frozen and freeze-dried to remove any remaining liquid.

The samples were then transferred to a vial with a screw cap holding a septa and PCTFE washer to make a vacuum seal, and the samples reacted with $100 \%$ orthophosphoric acid at $90^{\circ} \mathrm{C}$ using a Micromass Multicarb Sample Preparation System. The carbon dioxide produced was dried and transferred cryogenically into a VG SIRA mass spectrometer for isotopic analysis. Carbon and oxygen isotopic ratios were measured on the delta scale, in comparison to the international 
standard VPDB calibrated using the NBS19 standard (Craig 1957; Coplen 1995). Repeated measurements on international and in-house standards show that the analytical error is better than $\pm 0.08 \%$ for carbon and $\pm 0.10 \%$ for oxygen.

\section{Results}

\section{Dentine carbon and nitrogen isotope results}

The dentine results for humans and animals are given in the Appendix and shown in Fig. 3. The animal dentine carbon stable isotope results range from -21.9 to $-20.6 \%$ with a mean of $-21.5 \pm 0.5 \%$ (range $=1.4, \mathrm{n}=6$ ). The nitrogen stable isotope results range from 5.3 to $8.0 \%$ with a mean of $6.4 \pm 1.0 \%$ (range $=2.6$, $\mathrm{n}=6$ ). The two ovicaprid samples have higher $\delta^{13} \mathrm{C}$ and $\delta^{15} \mathrm{~N}$ values than the four cattle samples (by 0.8 and $1.9 \%$, respectively), although sample size is too small for statistical analyses.

The human dentine carbon stable isotope results range from -21.1 to $-19.2 \%$ o with a mean of $-19.9 \pm 0.5 \%$ (range $=2.8 \%, \mathrm{n}=14)$. The nitrogen stable isotope results range from 8.7 to $13.8 \%$ with a mean of $10.9 \pm 1.3 \%$ (range $=5.1 \%$, $\mathrm{n}=14$ ). The mean differences between human and herbivore values are $1.7 \%$ for $\delta^{13} \mathrm{C}$ and $4.4 \%$ for $\delta^{15} \mathrm{~N}$.

As can be seen in Fig. 3, there are some differences between the isotope values of humans buried in different sites, despite the small sample size. The data are summarized by site in Table 1. The two individuals from St Catherine's Church

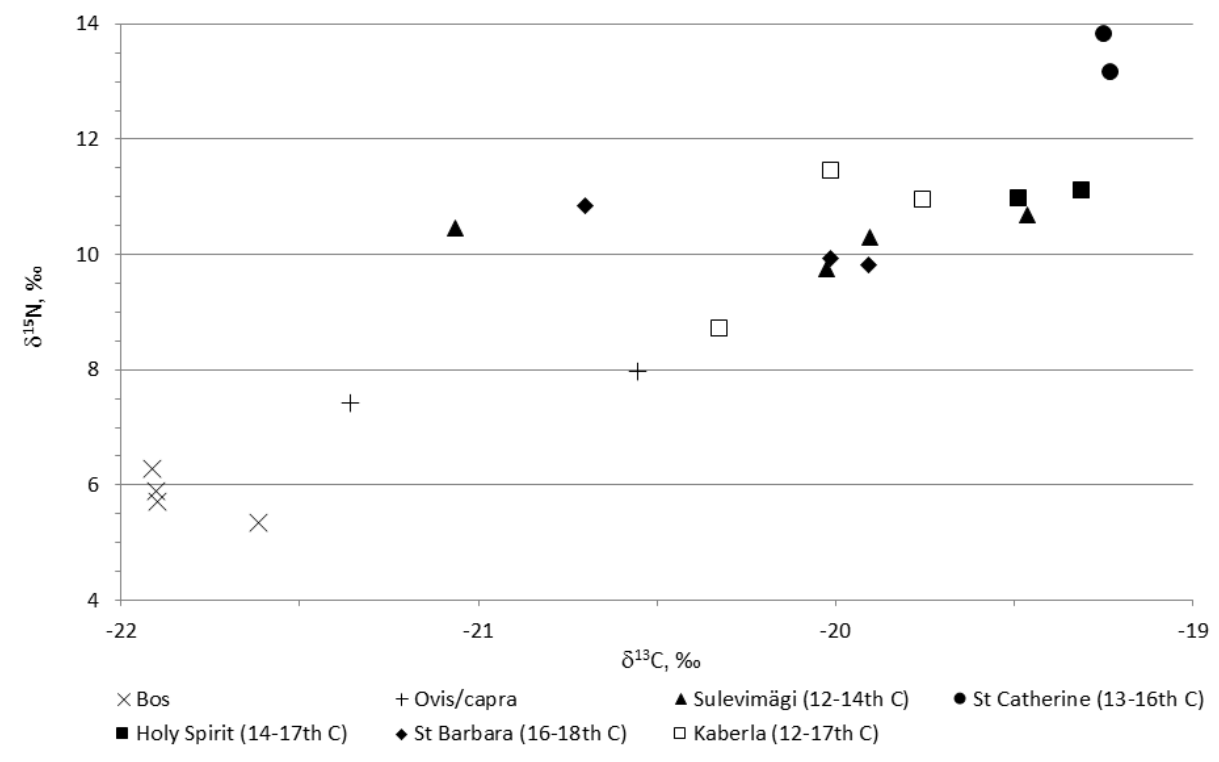

Fig. 3. Scatter plot showing $\delta^{13} \mathrm{C}$ and $\delta^{15} \mathrm{~N}$ dentine results from humans and animals. 
have the highest values in both $\delta^{13} \mathrm{C}$ and $\delta^{15} \mathrm{~N}$ (with differences between mean human and herbivore values of 2.3 and $7.1 \%$ in $\delta^{13} \mathrm{C}$ and $\delta^{15} \mathrm{~N}$, respectively). The two individuals from the Church of the Holy Spirit have relatively high $\delta^{13} \mathrm{C}$ values but typical $\delta^{15} \mathrm{~N}$ values (the mean difference between the human and herbivore $\delta^{13} \mathrm{C}$ value is $2.1 \%$ ). The three remaining sites, St Barbara Cemetery, Sulevimägi Cemetery and Kaberla, have broadly similar results, although we note that the individuals from Sulevimägi Cemetery have a relatively wide range of $\delta^{13} \mathrm{C}$ values, while those from Kaberla have a relatively wide range of $\delta^{15} \mathrm{~N}$ values.

\section{Enamel carbon isotope results}

The tooth enamel carbonate isotope results for humans and animals are given in the Appendix and shown in Figs 4 and 5. The carbonate carbon stable isotope results for the human samples range from -13.6 to $-12.5 \%$ with a mean of $-13.2 \pm 0.4 \%$ (range $=1.1, \mathrm{n}=14)$.

The data are summarized by site in Table 1 . The data may fall into two groups, with the two individuals from the Church of the Holy Spirit and two of the individuals from Sulevimägi Cemetery having enamel $\delta^{13} \mathrm{C}$ values on average $0.8 \%$ higher than the other analysed individuals. Unlike the dentine $\delta^{13} \mathrm{C}$ values, the individuals from St Catherine's Church have typical enamel $\delta^{13} \mathrm{C}$ values.

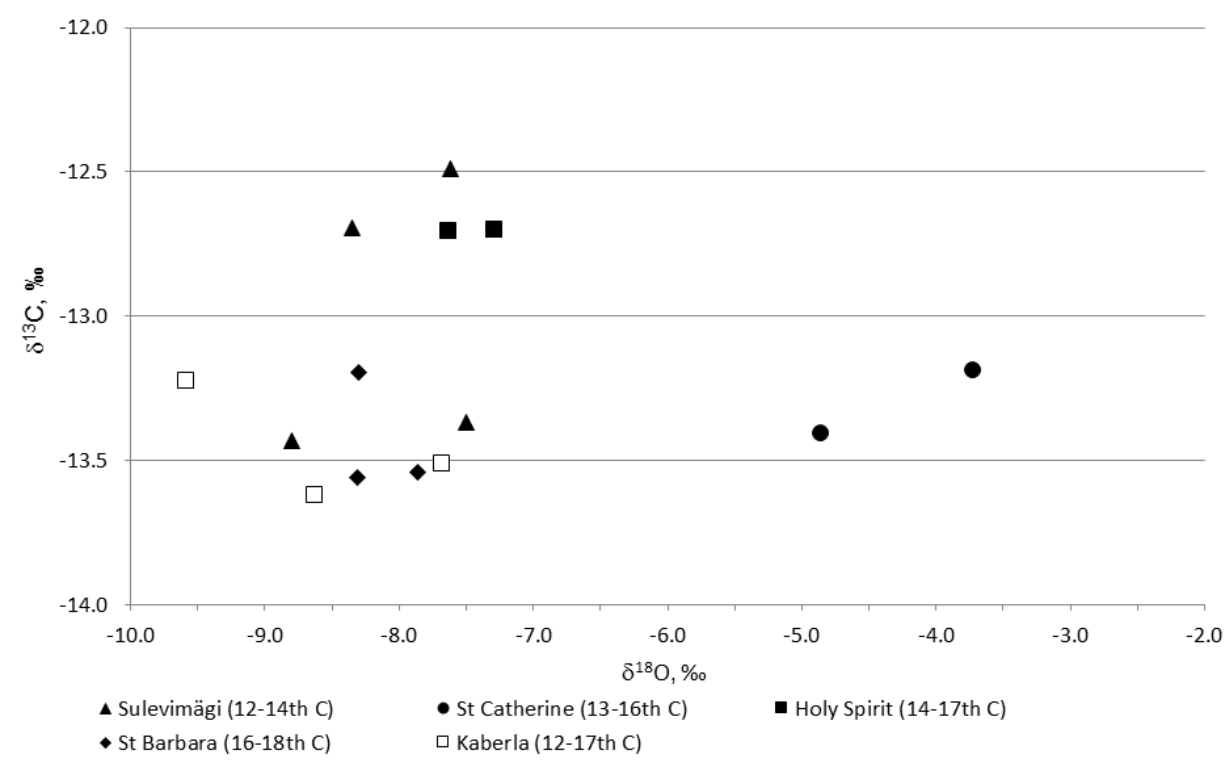

Fig. 4. Scatter plot showing $\delta^{18} \mathrm{O}$ and $\delta^{13} \mathrm{C}$ enamel carbonate results from humans. 


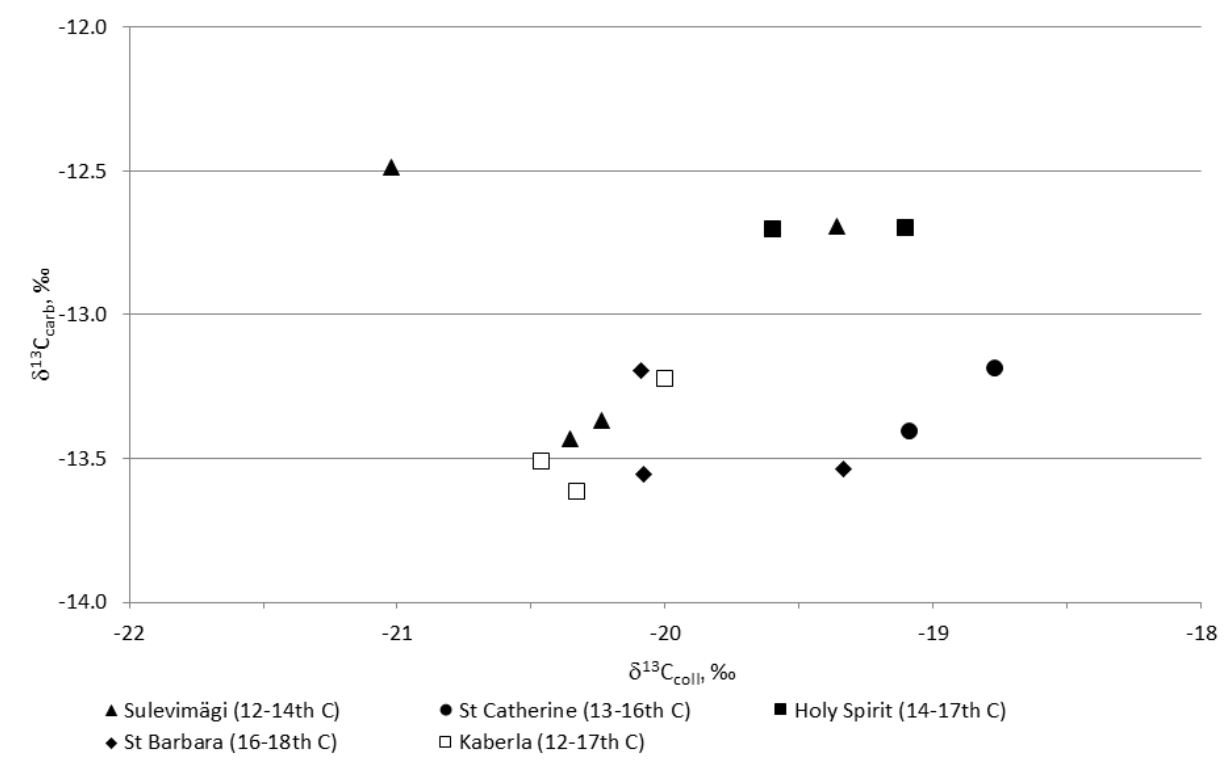

Fig. 5. Scatter plot showing $\delta^{13} \mathrm{C}$ enamel carbonate and $\delta^{13} \mathrm{C}$ bone collagen results from humans.

\section{Bone collagen carbon and nitrogen isotope results}

The bone collagen results for humans are given in the Appendix and shown in Fig. 6. The human bone collagen $\delta^{13} \mathrm{C}$ values range from -21.0 to $-18.8 \%$ with a mean of $-19.8 \pm 0.6 \%$ (range $=2.3, \mathrm{n}=14$ ). The $\delta^{15} \mathrm{~N}$ values range from 8.9 to $13.7 \%$ with a mean of $10.9 \pm 1.4 \%$ (range $=4.7, \mathrm{n}=14$ ). The mean differences between human bone collagen data and the herbivore dentine values are $1.7 \%$ for $\delta^{13} \mathrm{C}$ and $4.4 \%$ for $\delta^{15} \mathrm{~N}$.

The data are summarized by site in Table 1. As can be seen in Fig. 6, there are some differences between the isotope values of humans buried in different sites, despite the small sample size. These patterns are very similar to those of the dentine results. The two individuals from St Catherine's Church have the highest bone collagen values in both $\delta^{13} \mathrm{C}$ and $\delta^{15} \mathrm{~N}$. Again, the two individuals from the Church of the Holy Spirit have slightly elevated bone collagen $\delta^{13} \mathrm{C}$ values but typical $\delta^{15} \mathrm{~N}$ values. As with the dentine results, the three remaining sites, St Barbara, Sulevimägi and Kaberla cemeteries, have broadly similar bone collagen results, and again we note that Sulevimägi Cemetery has a relatively wide range of $\delta^{13} \mathrm{C}$ values, and Kaberla has a relatively wide range of $\delta^{15} \mathrm{~N}$ values. One individual from St Barbara Cemetery (LTL06) is notably different from the dentine pattern, having slightly elevated bone collagen $\delta^{13} \mathrm{C}$ and $\delta^{15} \mathrm{~N}$ values. 


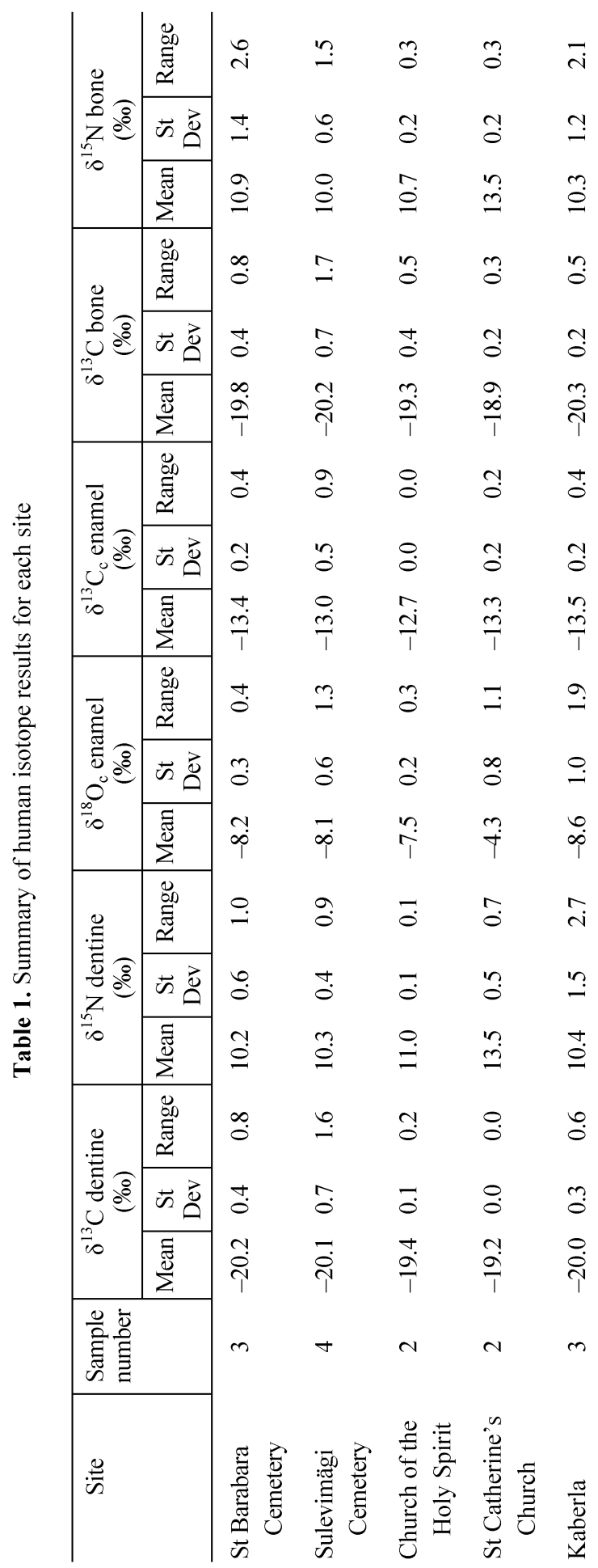




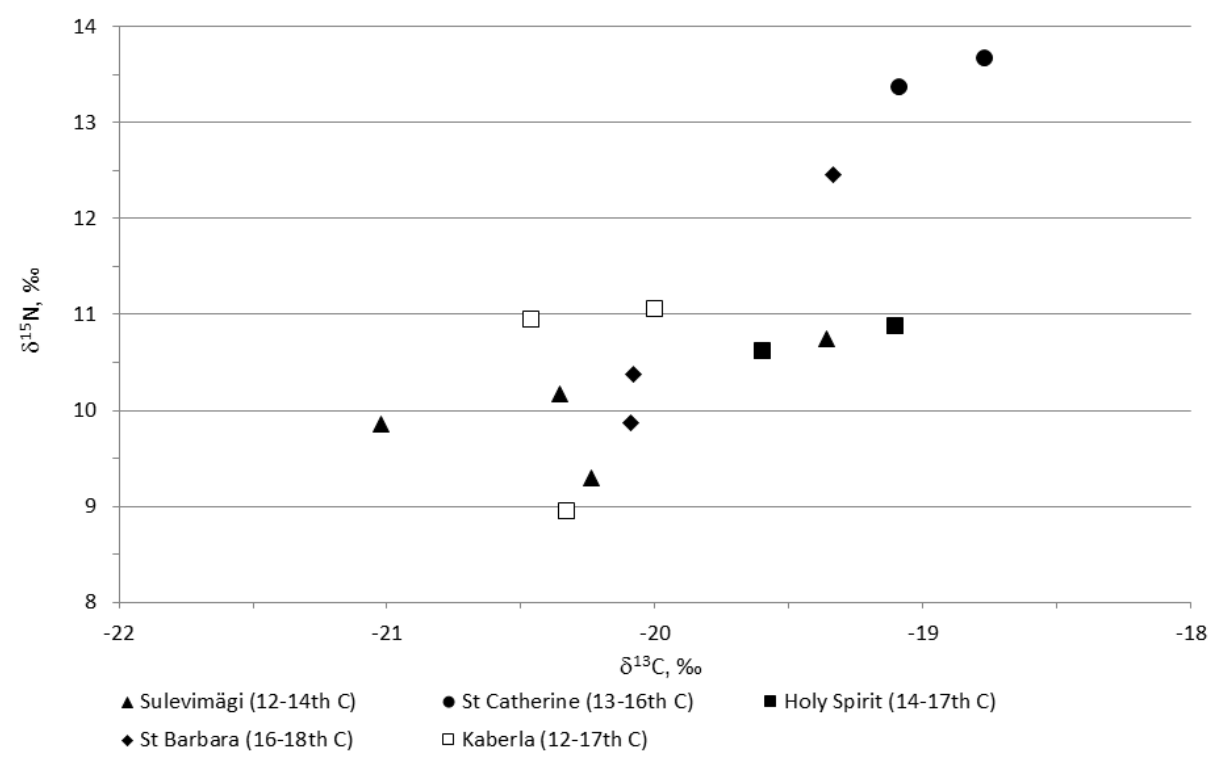

Fig. 6. Scatter plot showing $\delta^{13} \mathrm{C}$ and $\delta^{15} \mathrm{~N}$ bone collagen results from humans.

\section{Differences between carbon isotope values of dentine and bone collagen}

Direct comparisons can be made between dentine and bone collagen values, which reflect diet during childhood and the last years of life, respectively (data shown in the Appendix). Differences greater than ca $0.5 \%$ between the two tissues are likely to reflect a notable change in diet during life, any value less than this may well be the result of machine error or 'noise'. Three individuals have differences greater than $0.5 \%$. The largest differences in $\delta^{13} \mathrm{C}$ and $\delta^{15} \mathrm{~N}$ are 1.4 and $1.6 \%$, respectively, and are both seen in an individual from St Barbara Cemetery (LTL06). Both isotopic ratios increase during life. Two individuals from Sulevimägi Cemetery show changes in $\delta^{13} \mathrm{C}$. LTL14 shows an increase in $\delta^{13} \mathrm{C}$ by $0.7 \%$ during life, while LTL20 shows a decrease during life of $1.1 \%$.

\section{Enamel oxygen isotope results}

As the local baseline value is uncertain and given the difficulties in converting human oxygen isotope values into drinking water values associated with conversion equations and error propagation (see discussions in Pollard et al. 2011; Pryor et al. 2014), the oxygen isotope results will be discussed as unconverted values. The data are given in the Appendix and shown in Fig. 4. The $\delta^{18} \mathrm{O}_{\mathrm{VPDB}}$ values range from -9.7 to $-3.7 \%$, with a mean of $-7.6 \pm 1.5 \%$ ( range $=5.9, \mathrm{n}=14)$. As can be seen from Fig. 4, there are two clear outliers, the two samples from St Catherine's Church (LTL26 and LTL28). These results are also statistical outliers, lying more than 3 times the interquartile range above quartile 3. 


\section{Discussion}

Throughout this discussion it should be borne in mind that sample sizes are limited and the differences between groups are generally fairly small. Nevertheless, the consistency of isotopic differences between groups across the different tissues lends weight to the inferences made here. It should also be noted that the samples span a relatively long chronological period. While temporal differences do exist between sites, the large date ranges associated with each site and the overlap between them make a chronological comparison untenable. Nevertheless, it remains possible, indeed likely, that diet did change through time.

\section{Dentine carbon and nitrogen isotope evidence for childhood dietary protein}

The animal dentine results are fairly typical for European Holocene herbivore data. That the ovicaprid isotope values are higher in both $\delta^{13} \mathrm{C}$ and $\delta^{15} \mathrm{~N}$ than the cows suggests that the two species were raised in slightly different environments, or perhaps that the ovicaprids consumed small amounts of $\mathrm{C}_{4}$ foodstuffs.

The human dentine isotope results are typical for those found in Holocene European samples, and the mean differences between human and herbivore isotope values are typical for a single trophic level increase. In general, these results suggest a diet based on $\mathrm{C}_{3}$ plants and animals. We note, however, that the range in $\delta^{15} \mathrm{~N}(5.1 \%)$ is large, suggesting some variation in the diets of the individuals sampled in regard to the amount of animal protein consumed or the trophic level of the protein consumed (i.e. terrestrial or aquatic protein).

When the human dentine results are considered by site, it is clear that some of this variation reflects differences in the childhood diets of people buried in different sites, although the small sample sizes here do mean that these results should be treated with caution. Nevertheless, the individuals buried at St Catherine's Church had diets during childhood that had relatively high $\delta^{13} \mathrm{C}$ and $\delta^{15} \mathrm{~N}$ values. The $\delta^{15} \mathrm{~N}$ values are clearly indicative of the consumption of protein from a higher trophic level than the analysed herbivores. The $\delta^{13} \mathrm{C}$ values, however, are somewhat ambiguous in that they are higher than expected given the herbivore $\delta^{13} \mathrm{C}$ values, but still within the typical range for a European $\mathrm{C}_{3}$ diet. The most parsimonious explanation for elevated $\delta^{13} \mathrm{C}$ and $\delta^{15} \mathrm{~N}$ values is a small component of marine fish in the diet. This conclusion would correspond well with historical data of fish (dried cod, salted herring as well as fresh marine and fresh water species) being a dietary staple in Hanseatic towns (Orton et al. 2011; Yeh et al. 2014). Alternatively, it is possible that the $\delta^{15} \mathrm{~N}$ values reflect a diet that included a very large proportion of animal protein or a diet that included freshwater fish. In this scenario, the $\delta^{13} \mathrm{C}$ values could reflect the consumption of plants with relatively high $\delta^{13} \mathrm{C}$ values (whether $\mathrm{C}_{3}$ or $\mathrm{C}_{4}$ ) or animals fed upon such plants, or it may be that the faunal data do not reflect the full range of isotopic variation 
due to the small sample size (however, the fact that both of the samples from this site show similar $\delta^{13} \mathrm{C}$ values argues against this possibility). Nevertheless, the simplest explanation remains the consumption of small amounts of marine foods.

The individuals from the Church of the Holy Spirit consumed typical amounts of animal protein, but ate a diet that had somewhat higher $\delta^{13} \mathrm{C}$ values than those individuals from the remaining three sites. Again, this could either reflect the consumption of plants with relatively high $\delta^{13} \mathrm{C}$ values (whether $\mathrm{C}_{3}$ or $\mathrm{C}_{4}$ ) or animals fed upon such plants, or it may be that the faunal data do not reflect the full range of isotopic variation.

The remaining individuals generally have values that indicate a $\mathrm{C}_{3}$ based diet combined with the consumption of animal protein from animals fed on $\mathrm{C}_{3}$ plants. The individuals buried at Kaberla show the most variety in the amount of animal protein consumed during childhood, while individuals from Sulevimägi Cemetery show the most variety in carbon isotope values, either through variation in the $\delta^{13} \mathrm{C}$ values of the $\mathrm{C}_{3}$ plants consumed, or through differential consumption of $\mathrm{C}_{4}$ plants.

\section{Carbon isotope evidence for childhood whole diet}

The human carbonate carbon isotope results indicate childhood diets based on $\mathrm{C}_{3}$ carbohydrate. There are four individuals with slightly elevated enamel $\delta^{13} \mathrm{C}$ values - the two individuals from the Church of the Holy Spirit and two (of four) individuals from Sulevimägi Cemetery. It is possible that the apparent difference is due to sampling bias, however given that three of these results were also identified as having relatively high dentine $\delta^{13} \mathrm{C}$ values it seems likely that these results reflect real dietary differences. Considering these four results in conjunction with the dentine $\delta^{13} \mathrm{C}$ values, it seems most likely that these individuals were consuming some plants with high $\delta^{13} \mathrm{C}$ values (whether $\mathrm{C}_{3}$ or $\mathrm{C}_{4}$ ) directly, rather than consuming animals fed upon such plants. It is more likely that these individuals consumed $\mathrm{C}_{4}$ plants than $\mathrm{C}_{3}$ plants with high $\delta^{13} \mathrm{C}$ values. Common millet (Panicum miliaceum) has been found in small amounts in the archaeological deposits of mediaeval Estonia, in the Old Town of Tallinn (at Sulevimägi) and Tartu (Sillasoo \& Hiie 2007). Only relatively small amounts of millet or other $\mathrm{C}_{4}$ plants would have had to have been consumed to cause such small isotopic shifts, although they would have had to have been regular components of the diet. On the other hand, large amounts of high $\delta^{13} \mathrm{C}$ value $\mathrm{C}_{3}$ plants would have had to have been consumed to cause such shifts, and these individuals would have had to have consumed a large amount of plant foods grown in particular environmental conditions, probably imported from elsewhere, and not available to the rest of the sampled population of Tallinn and Kaberla. While this is possible, it seems unlikely due to the practicalities of such an undertaking. Regardless of whether these plants were $\mathrm{C}_{3}$ or $\mathrm{C}_{4}$, it seems that these individuals had preferential access to plants that were different (whether in terms of growing conditions or species) from those consumed by the other analysed individuals. 
It is interesting to note that the two individuals from St Catherine's Church who had high $\delta^{13} \mathrm{C}$ dentine values did not have high $\delta^{13} \mathrm{C}$ enamel values. This suggests that the individuals from St Catherine's Church ate dietary protein with higher $\delta^{13} \mathrm{C}$ values than the carbohydrate component of their diet. This suggests they consumed a diet containing (a small proportion of) marine foods combined with $\mathrm{C}_{3}$ plants and animals.

\section{Bone collagen carbon and nitrogen isotope evidence for adult dietary protein}

The human bone collagen results indicate adult diets based mainly on $\mathrm{C}_{3}$ plants and animals fed upon $\mathrm{C}_{3}$ plants. The range of variation in the $\delta^{15} \mathrm{~N}$ values again indicates that there was variety in the diets of the sampled individuals.

Comparing the results by site again suggests that site differences account for some of the variation in adult diets (although we note that the sample sizes are small). The adult diets of the individuals buried at St Catherine's Church and one individual from St Barbara Cemetery (LTL06) had elevated $\delta^{15} \mathrm{~N}$ values and slightly elevated $\delta^{13} \mathrm{C}$ values. While all of the explanations given for the dentine results above remain possible, on balance and considering the enamel carbonate data it is likely that these results reflect the consumption of a small amount of marine fish.

The two individuals from the Church of the Holy Spirit and one individual from Sulevimägi Cemetery (LTL16) consumed some protein with slightly elevated $\delta^{13} \mathrm{C}$ values compared to the remaining individuals. Again there are various explanations for this pattern, noted above, but the most parsimonious explanation is the consumption of small amounts of $\mathrm{C}_{4}$ plants, probably millet.

The individuals from Kaberla and the remaining individuals from St Barbara Cemetery and Sulevimägi Cemetery consumed diets based on $\mathrm{C}_{3}$ plants and animals fed upon $\mathrm{C}_{3}$ plants.

\section{Oxygen isotope evidence for mobility}

The oxygen results indicate that the majority of the population drank water from the same source during childhood. The most parsimonious explanation is that these people were born locally.

The two individuals buried inside St Catherine's Church (LTL26 and LTL28) drank water with a notably different $\delta^{18} \mathrm{O}$ values during childhood. This suggests that these individuals migrated to Tallinn during life, probably from an area with a warmer climate. This fits well with the archaeological and historical evidence that only foreigners were likely to be buried inside the church. It remains possible, however, that they lived locally and consumed water with different oxygen isotope values to the rest of the analysed individuals. This could be due to human behaviours, such as importation, brewing, vinification, stewing or fish consumption (Daux et al. 2008; Warriner \& Tuross 2009; Brettell et al. 2012; Lightfoot et al. 2014). In this scenario, their different $\delta^{18} \mathrm{O}$ values would be related to status rather than migration. However, the isotope values of these individuals are very 
different to the other analysed individuals ( 3.2 and 4.4\%, respectively), which would require a significant lifestyle difference during childhood in order to cause such a change in the isotope values. Either the water they consumed would have to be almost entirely shifted by ca 3-4\%o compared to the other individuals' ingested water, or a smaller proportion of their ingested water could be isotopically shifted by a correspondingly larger amount. While this is theoretically possible, given the archaeological and historical evidence for burial of foreigners inside the church, we would argue that the most parsimonious explanation is that these individuals were migrants.

\section{Discussion by site and individual}

The four individuals from Sulevimägi Cemetery, thought to represent a Christian (probably Russian Orthodox) population, have $\delta^{18} \mathrm{O}$ values consistent with a local origin. However, this is not incompatible with the hypothesis that these individuals were Novgorodian merchants, as people born in Novgorod are likely to have similar oxygen isotope values to people born in Tallinn (the oxygen isotope values of precipitation for these two regions are -11.6 and $-11.4 \%$, respectively, calculated using www.waterisotopes.org). Of the four individuals sampled, two people (LTL14 and LTL18) have dietary isotope values suggesting diets based on $\mathrm{C}_{3}$ plants and animals fed upon $\mathrm{C}_{3}$ plants throughout life. The third individual (LTL20) has somewhat contradictory isotope results - the carbonate $\delta^{13} \mathrm{C}$ values indicate that there may have been a small $\mathrm{C}_{4}$ component to the childhood diet, while the contemporary dentine results show no evidence for $\mathrm{C}_{4}$ consumption. It may be that any $\mathrm{C}_{4}$ input was in amounts below the level of detectability in collagen, but high enough to be visible in the enamel data. In later life, this individual has the lowest bone collagen $\delta^{13} \mathrm{C}$ value, suggesting that if any $\mathrm{C}_{4}$ plants were consumed during childhood this was not continued in adulthood. The fourth individual (LTL16) has $\delta^{13} \mathrm{C}$ values that indicate a small component of $\mathrm{C}_{4}$ plants in the diet throughout life.

The two samples from St Catherine's Church are thought to represent monks or merchants. The oxygen isotope results strongly suggest that these two individuals are immigrants to Tallinn. They are also distinctive in terms of their diet; both the dentine and bone collagen isotope results show relatively high $\delta^{13} \mathrm{C}$ and $\delta^{15} \mathrm{~N}$ values. However, the enamel $\delta^{13} \mathrm{C}$ values are typical of a $\mathrm{C}_{3}$ diet. This shows that the protein component of the diet had high ${ }^{13} \mathrm{C}$ values, while the carbohydrate component did not. It is therefore likely that these individuals consumed a small amount of marine foods throughout life, in both their homeland and their burial place. A small proportion of marine protein in their adult diets would fit with isotopic evidence for the consumption of seafood by monks during fasting periods in other monastic populations in Denmark (Yoder 2012) and England (Müldner $\&$ Richards 2005). The isotopic evidence is consistent with the hypothesis that these individuals were Dominican monks who travelled from (coastal) Germany or Denmark to Tallinn. 
The two individuals buried at the Church of the Holy Spirit are thought to represent urban residents. Their oxygen isotope results suggest that they were both born locally. The $\delta^{13} \mathrm{C}$ values of these individuals are a little higher than the sample mean in all three tissues, suggesting that the carbon isotope enriched food source is likely represented in the carbohydrate portion of the diet. This suggests that these individuals consumed a small amount of $\mathrm{C}_{4}$ plants directly (and possibly via animals eating $\mathrm{C}_{4}$ plants). The consumption of $\mathrm{C}_{4}$ plants by mediaeval populations and individuals has been suggested in Poland (Reitsema et al. 2010) and Croatia (Lightfoot et al. 2012).

The three individuals from St Barbara Cemetery, thought to represent native Estonians, have $\delta^{18} \mathrm{O}$ values suggestive of local origins. Two of the individuals (LTL02 and LTL04) have $\delta^{13} \mathrm{C}$ and $\delta^{15} \mathrm{~N}$ values that suggest they ate diets based on $\mathrm{C}_{3}$ plants and animals fed upon $\mathrm{C}_{3}$ plants throughout life. The third individual (LTL06), however, shows notable dietary variation through life with increases in both $\delta^{13} \mathrm{C}$ and $\delta^{15} \mathrm{~N}$ values. During childhood, this individual consumed a diet based on $\mathrm{C}_{3}$ plants and animals fed upon $\mathrm{C}_{3}$ plants. At some time, at least several years before death, this individual's diet changed, most likely through the inclusion of a small proportion of marine protein. It is possible that this represents a change in diet related to moving from a(n inland) rural area to Tallinn, or represents a change in social status or cultural customs.

Finally, the samples from Kaberla represent a rural village population thought to be comprised of native Estonians. The oxygen isotope results suggest that these individuals are most likely locally born. For all three individuals the dietary isotope results indicate a diet based on $\mathrm{C}_{3}$ plants and animals fed upon $\mathrm{C}_{3}$ plants throughout life. One individual (LTL12) has the lowest $\delta^{15} \mathrm{~N}$ results of the humans sampled for this study in both dentine and bone collagen, suggesting that they ate low quantities of animal protein throughout life.

\section{Comparison between sites}

While it should be emphasized that all the individuals analysed in this study consumed diets that mainly comprised of $\mathrm{C}_{3}$ plants and animals fed upon $\mathrm{C}_{3}$ plants, minor differences do exist between the analysed sites and the groups they represent.

The Kaberla individuals show that a rural peasant diet was largely, if not solely, based upon $\mathrm{C}_{3}$ plants and animals fed upon $\mathrm{C}_{3}$ plants. The individuals from St Barbara Cemetery may also have been rural peasants who moved to Tallinn during a famine. It is then likely that a diet comprising solely or mainly of $\mathrm{C}_{3}$ foodstuffs was eaten in both town and country. To this diet the individuals analysed from the Church of the Holy Spirit, and one or two individuals from Sulevimägi, probably added small amounts of $\mathrm{C}_{4}$ foods, possibly millet. It has been suggested that millet in mediaeval Estonia was consumed by urban middle classes and was presumably imported from southern Baltic regions (Sillasoo \& Hiie 2007, 89). 
The two individuals from St Catherine's Church, isotopically identified as migrants, consumed small amounts of marine foods in both childhood and adult life suggesting that after migrating to Tallinn they continued to consume familiar foods. Given the burial context of these two individuals in a Friary, it is possible that they represent monks or foreign merchants consuming fish during those periods when meat was forbidden. One can therefore speculate that marine foodstuffs either had high social value in mediaeval Tallinn or should be seen in relation to the Roman Catholic fasting practices. If this is the case, then it is possible that the individual from St Barbara Cemetery whose diet shifted to include marine foods (LTL06) attained or aspired to higher social status during life and adhered to Christian dietary customs.

It remains possible that the differences seen between sites are not a reflection of social, cultural or ethnic differences, but rather represent changes in diet through time. However, two or three of the individuals from the earliest site, Sulevimägi, and the individuals from latest site, St Barbara Cemetery, ate isotopically similar diets. The sites with the most distinct diets, St Catherine's Church and the Church of the Holy Spirit, fall chronologically between Sulevimägi and St Barbara Cemetery. This, combined with the good fit between isotope results and the archaeological evidence for social group, suggests that the primary factor explaining the variation between sites is more likely to be ethnicity and social status than chronology.

The individuals analysed represent different groups in Tallinn's society, probably including merchants, monks, urban Estonians and both urban and rural low-status Estonians. The probable merchants and the likely Estonians buried in the Church of the Holy Spirit included isotopically identifiable amounts of millet in their diets, while the probable monks included fish or seafood. This suggests a link between diet and social group, with millet being consumed by relatively wealthy individuals and seafood by monks. Ethnicity and social status were closely linked in mediaeval Tallinn, and it seems that in accordance with the historical evidence food was indeed used to encode social and cultural values.

\section{Conclusion}

Isotopic investigations of diet in mediaeval Tallinn and Kaberla have provided useful insights into the diets, social statuses and life histories of the analysed individuals. Given the small sample sizes involved, we cannot claim to characterize the diets of social groups, but it is clear that in general diets in mediaeval Tallinn and Kaberla consisted of $\mathrm{C}_{3}$ plants, such as wheat, rye and barley, and animals fed upon $\mathrm{C}_{3}$ plants. Nevertheless, some individuals have small isotopic differences which indicate the regular consumption of small amounts of food with different isotopic values, such as fish and millet. It is likely that the consumption of fish and millet directly correlates with the ethnicity and/or social status of the individuals analysed. 


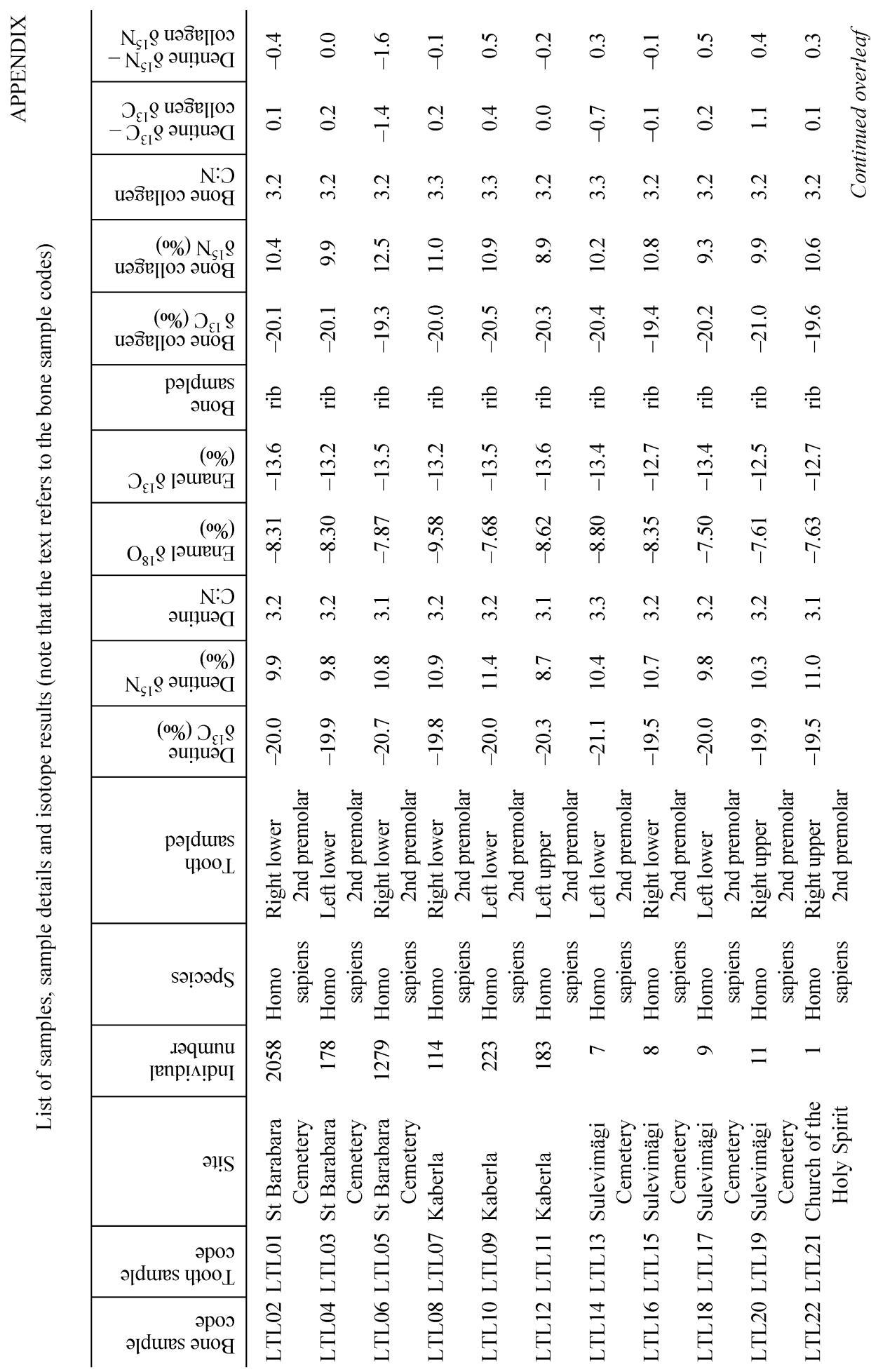




\begin{tabular}{|c|c|c|c|c|c|c|c|c|c|c|c|}
\hline 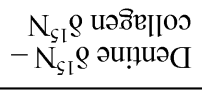 & ָุ & 'n & $\ddot{q}$ & $\stackrel{\pi}{\Xi}$ & $\stackrel{\tilde{I}}{\Xi}$ & $\stackrel{\pi}{\Xi}$ & $\stackrel{\pi}{\Xi}$ & $\stackrel{\pi}{\Xi}$ & $\stackrel{\pi}{\beth}$ & $\stackrel{\pi}{\Xi}$ & $\stackrel{\pi}{\Xi}$ \\
\hline 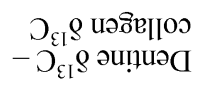 & $\stackrel{N}{9}$ & กั & $\ddot{q}$ & $\stackrel{\pi}{\Omega}$ & $\stackrel{\pi}{\beth}$ & $\stackrel{\pi}{=}$ & $\stackrel{\pi}{\Xi}$ & $\stackrel{\pi}{\Xi}$ & $\stackrel{\pi}{\Omega}$ & $\stackrel{\pi}{\Xi}$ & $\stackrel{\pi}{=}$ \\
\hline 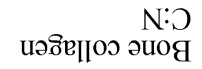 & $\ddot{n}$ & rִ & $\stackrel{n}{n}$ & $\stackrel{\pi}{\Xi}$ & $\stackrel{\pi}{a}$ & $\stackrel{\pi}{\beth}$ & $\stackrel{\pi}{\Xi}$ & $\stackrel{\pi}{\beth}$ & $\stackrel{\pi}{\beth}$ & $\stackrel{\pi}{a}$ & $\stackrel{\pi}{\beth}$ \\
\hline 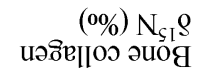 & 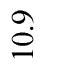 & $\stackrel{\nabla}{\check{2}}$ & $\ddot{g}$ & $\stackrel{\pi}{\geq}$ & $\stackrel{\pi}{a}$ & $\stackrel{\pi}{\beth}$ & $\stackrel{\pi}{\Xi}$ & $\stackrel{\pi}{\Xi}$ & $\stackrel{\pi}{a}$ & $\stackrel{\pi}{a}$ & $\stackrel{\pi}{\Xi}$ \\
\hline 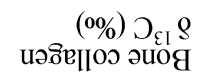 & $\vec{a}$ & $\vec{a}$ & $\begin{array}{l}\infty \\
\infty \\
\uparrow\end{array}$ & $\stackrel{\pi}{\beth}$ & $\stackrel{\pi}{\Xi}$ & $\stackrel{\pi}{\beth}$ & $\stackrel{\pi}{\beth}$ & $\stackrel{\pi}{\beth}$ & $\stackrel{\pi}{\beth}$ & $\stackrel{\pi}{\Xi}$ & $\stackrel{\pi}{\beth}$ \\
\hline $\begin{array}{r}\text { pərdurs } \\
\text { әuоg }\end{array}$ & : & 를 & 읖 & $\stackrel{\mathbb{a}}{\Xi}$ & $\stackrel{\pi}{\Xi}$ & $\stackrel{\pi}{\beth}$ & $\stackrel{\pi}{\beth}$ & $\stackrel{\pi}{\Xi}$ & $\stackrel{\pi}{\Xi}$ & $\stackrel{\mathbb{a}}{\beth}$ & $\stackrel{\pi}{\beth}$ \\
\hline 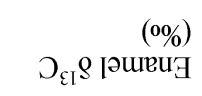 & $\stackrel{i}{i}$ & $\stackrel{\nabla}{T}$ & $\stackrel{\dddot{1}}{i}$ & $\underset{\mathfrak{T}}{\mathrm{T}}$ & $\underset{T}{T}$ & $\stackrel{9}{T}$ & 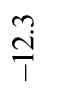 & $\stackrel{n}{1}$ & $\stackrel{n}{1}$ & $\stackrel{9}{i}$ & $\stackrel{n}{i}$ \\
\hline 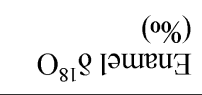 & $\stackrel{\text { }}{i}$ & $\stackrel{\infty}{\infty}$ & $\stackrel{i}{i}$ & $\hat{a}$ & $\stackrel{?}{\stackrel{0}{0}}$ & $\stackrel{\infty}{\stackrel{\infty}{1}}$ & $\underset{i}{\nexists}$ & $\stackrel{\circ}{9}$ & $\bar{m}$ & $\stackrel{\stackrel{\infty}{\sim}}{=}$ & $\stackrel{2}{a}$ \\
\hline $\begin{array}{r}\mathrm{N}: \text { ว } \\
\text { әи!ฺนว }\end{array}$ & $\vec{m}$ & $\bar{m}$ & $\ddot{n}$ & $\ddot{n}$ & $\stackrel{\sim}{n}$ & $\bar{m}$ & $\stackrel{\pi}{\Xi}$ & $\stackrel{\pi}{\beth}$ & $\tilde{n}$ & ñ. & $\stackrel{n}{n}$ \\
\hline 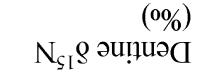 & $\exists$ & $\stackrel{\infty}{\ddot{2}}$ & $\ddot{n}$ & $\ddot{n}$ & $\hat{\sigma}$ & $m$ & $\stackrel{\pi}{\beth}$ & $\stackrel{\pi}{\Xi}$ & $\stackrel{0}{\infty}$ & $\underset{\sim}{\stackrel{\Delta}{*}}$ & बें \\
\hline $\begin{array}{l}\text { (o\%) } \mathcal{D}_{\mathcal{E I I}} \mathrm{g} \\
\text { әu!̣uəC }\end{array}$ & & $\stackrel{2}{1}$ & $\stackrel{2}{\frac{1}{1}}$ & $\frac{a}{i}$ & $\frac{a}{i}$ & $\frac{0}{i}$ & $\stackrel{\pi}{\geq}$ & $\stackrel{\pi}{\Xi}$ & $\stackrel{\leftrightarrow}{\oplus}$ & $\stackrel{\dot{\sim}}{\top}$ & $\frac{\sigma}{i}$ \\
\hline $\begin{array}{l}\text { pə|dures } \\
\text { प100 L }\end{array}$ & 离 & 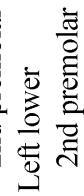 & 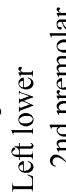 & 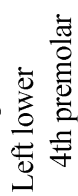 & 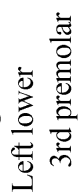 & 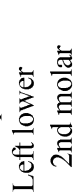 & 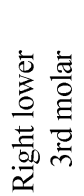 & 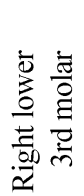 & 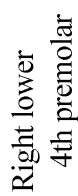 & 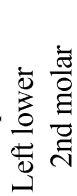 & 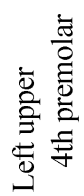 \\
\hline səழ̣əds & 芯 & 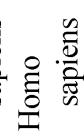 & 竎 & 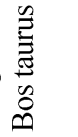 & 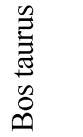 & 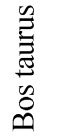 & $\frac{n}{3}$ & $\frac{\tilde{n}}{\tilde{b}}$ & 营 & $\frac{n}{3}$ & 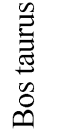 \\
\hline 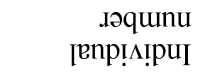 & $N$ & - & $\nabla$ & $\stackrel{\pi}{\Xi}$ & $\stackrel{\pi}{\Xi}$ & $\stackrel{\pi}{\varrho}$ & $\stackrel{\pi}{\beth}$ & $\stackrel{\pi}{\Xi}$ & $\stackrel{\pi}{\Xi}$ & $\stackrel{\pi}{\beth}$ & $\stackrel{\pi}{\varrho}$ \\
\hline Әł!S & 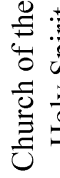 & 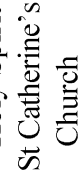 & 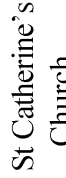 & 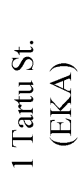 & 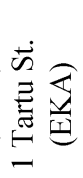 & 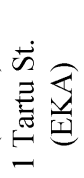 & 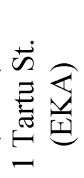 & 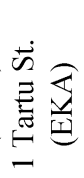 & 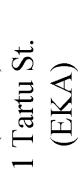 & 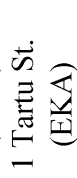 & 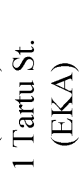 \\
\hline 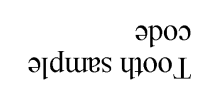 & 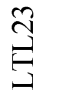 & 咨 & 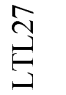 & 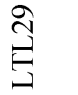 & $\stackrel{尺}{\stackrel{9}{G}}$ & $\overrightarrow{\underline{G}}$ & 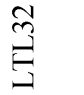 & $\stackrel{\mathscr{M}}{G}$ & 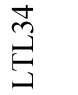 & 急 & 管 \\
\hline $\begin{array}{r}\text { әроэ } \\
\text { ग्राurs əuоg }\end{array}$ & $\stackrel{\stackrel{+}{G}}{\leftrightarrows}$ & 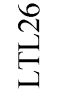 & 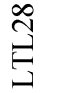 & $\stackrel{\pi}{\beth}$ & $\stackrel{\pi}{\Xi}$ & $\stackrel{\pi}{\beth}$ & $\stackrel{\pi}{\Xi}$ & $\stackrel{\pi}{\Xi}$ & $\stackrel{\pi}{\beth}$ & $\stackrel{\pi}{\Xi}$ & $\stackrel{\pi}{\beth}$ \\
\hline
\end{tabular}




\section{Acknowledgements}

We would like to thank Liina Maldre for her help with the animal remains and Raili Allmäe for their help with the human remains, also Mare Aun for consultations about Kaberla cemetery and Kaire Tooming for consultations about the Holy Spirit cemetery. The authors would also like to thank Ligia TrombettaLima, Catherine Kneale and James Rolfe (University of Cambridge) for their help with isotopic sample analysis. Emma Lightfoot would like to thank Darwin College, University of Cambridge for financial support. The article was written by the support of research projects of the Estonian Ministry of Education and Science (ETF9405 and IUT18-8).

\section{References}

Ambrose, S. H. 1990. Preparation and characterization of bone and tooth collagen for isotopic analysis. - Journal of Archaeological Science, 17: 4, 431-451.

Ambrose, S. H. \& Norr, L. 1993. Isotopic composition of dietary protein and energy versus bone collagen and apatite: purified diet growth experiments. - Prehistoric Human Bone: Archaeology at the Molecular Level. Eds J. Lambert \& G. Grupe. Springer-Verlag, New York, 1-37.

Anthony, D. W. 1997. Prehistoric migration as a social process. - Migrations and Invasions in Archaeological Explanation. Eds J. C. Chapman \& H. Hamerow. (BAR, International Series, 664.) Archaeopress, Oxford, 21-32.

Balasse, M., Ambrose, S. H., Smith, A. B. \& Price, T. D. 2002. The seasonal mobility model for prehistoric herders in the south-western cape of South Africa assessed by isotopic analysis of sheep tooth enamel. - Journal of Archaeological Science, 29: 9, 917-932.

Bocherens, H. \& Drucker, D. 2003. Trophic level isotopic enrichment of carbon and nitrogen in bone collagen: case studies from recent and ancient terrestrial ecosystems. - International Journal of Osteoarchaeology, 13: 1-2, 46-53.

Brettell, R., Montgomery, J. \& Evans, J. 2012. Brewing and stewing: the effect of culturally mediated behaviour on the oxygen isotope composition of ingested fluids and the implications for human provenance studies. - Journal of Analytical Atomic Spectrometry, 27: 5, 778-785.

Coplen, T. B. 1995. New IUPAC guidelines for the reporting of stable hydrogen, carbon and oxygen isotope-ratio data. - Journal of Research of the National Institute of Standards and Technology, 100: 285.

Craig, H. 1957. Isotopic standards for carbon and oxygen and correction factors for massspectromic analysis of carbon dioxide. - Geochimica et Cosmochimica Acta, 12: 1-2, 133-149.

Dansgaard, W. 1964. Stable isotopes in precipitation. - Tellus, 16, 436-438.

Daux, V., Lecuyer, C., Heran, M., Amiot, R., Simon, L., Fourel, F., Martineau, F., Lynnerup, N., Reychler, H. \& Escarguel, G. 2008. Oxygen isotope fractionation between human phosphate and water revisited. - Journal of Human Evolution, 55, 1138-1147.

De Niro, M. J. 1985. Postmortem preservation and alteration of in vivo bone collagen isotope ratios in relation to paleodietary reconstruction. - Nature, 317, 806-809.

Douglas, M. 1972. Deciphering a meal. - Dedalus, 101, 61-81.

Förstel, H. \& Hützen, H. 1983. Oxygen isotope ratios in German groundwater. - Nature, 304, 614-616.

Hansen, G. V. 1894. Aus Baltischen Vergangenheit. Miscellaneen aus dem Revaler Stadtarchiv, Reval. Harris, M. 1985. Good to Eat: Riddles of Food and Culture. Allen \& Unwin, London.

Harrison, R. G. \& Katzenberg, M. A. 2003. Paleodiet studies using carbon isotopes from bone apatite and collagen: examples from southern Ontario and San Nicolas Island, California. - Journal of Anthropological Archaeology, 22, 227-244. 
Hedges, R. E. M. \& Reynard, L. 2007. Nitrogen isotopes and the trophic level of humans in archaeology. - Journal of Archaeological Science, 34, 1240-1251.

Hedges, R. E. M., Clement, J. G., Thomas, D. L. \& O'Connell, T. C. 2007. Collagen turnover in the adult femoral mid-shaft: Modeled from anthropogenic radiocarbon tracer measurements. American Journal of Physical Anthropology, 133, 808-816.

Howland, M. R., Corr, L. T., Young, S. M. M., Jones, V., Jim, S., van der Merwe, N. J., Mitchell, A. D. \& Evershed, R. P. 2003. Expression of the dietary isotope signal in the compoundspecific delta(13) values of pig bone lipids and amino acids. - International Journal of Osteoarchaeology, 13, 1-2, 54-65.

Jim, S., Jones, V., Ambrose, S. H. \& Evershed, R. P. 2006. Quantifying dietary macronutrient sources of carbon for bone collagen biosynthesis using natural abundance stable carbon isotope analysis. - British Journal of Nutrition, 95, 1055-1062.

Johansen, P. 1951. Nordische Mission. Revals Gründung und die Schwedensiedlung in Estland. (Kungl. Vitterhets Historie och Antikvitets Akademiens Handlingar, 74.) Stockholm.

Johansen, P. 1965. Die Kaufmannskirche. - Die Zeit der Stadtgründung im Ostseeraum. VisbySymposiet för historiska vetenskaper 1963. (Acta Visbyensia, I.) Uppsala, 85-134.

Johansen, P. \& von zur Mühlen, H. 1973. Deutsch und Undeutsch im mittelalterlichen und frühneuzeitlichen Reval. (Ostmitteleuropa in Vergangenheit und Gegenwart, 15.) Böhlau Verlag, Köln.

Kadakas, V. 2006. Arheoloogilised uuringud kunagises Tallinna dominiiklaste Katariina kirikus, Vene tn 12. Tallinn. Excavation report in the archive of the Culture and Heritage Department of Tallinn.

Kadakas, V. \& Nilov, H. 2004. Various investigations in Tallinn and Harjumaa. - AVE, 2003, $160-175$.

Kadakas, U., Toos, G., Kalm, A., Nurk, R., Vedru, G., Tasuja, K. \& Kadakas, V. 2013. Medieval and early modern suburban site in Tallinn, Tartu Road. 1: Contexts and structures. AVE, 2012, 133-148.

Kala, T. 2006a. Ludeke Karwel, kogudusevaimulik. - Kala, T., Kreem, J. \& Mänd, A. Kümme keskaegset tallinlast. Varrak, Tallinn, 150-176.

Kala, T. 2006b. Vend Lucas, dominiiklane. - Kala, T., Kreem, J. \& Mänd, A. Kümme keskaegset tallinlast. Varrak, Tallinn, 177-206.

Kala, T. 2013. Jutlustajad ja hingede päästjad. Dominiiklaste ordu ja Tallinna Püha Katariina konvent. TLÜ Kirjastus, Tallinn.

Kangropool, R. 1992. Püha Barbara kabel ja kalmistu. - Vana Tallinn, II (VI). Tallinn, 6-15.

Kleinenberg, I. 1962. Tallinna vene kaubahoovi ajaloost XV-XVI sajandil. - TATÜ, 3, 241-257.

Lightfoot, E., Šlaus, M. \& O'Connell, T. C. 2012. Changing cultures, changing cuisines: cultural transitions and dietary change in Iron Age, Roman, and Early Medieval Croatia. - American Journal of Physical Anthropology, 148: 4, 543-556.

Lightfoot, E., Šlaus, M. \& O'Connell, T. C. 2014. Water consumption in Iron Age, Roman and Early Medieval Croatia. - American Journal of Physical Anthropology, 154: 4, 535-543.

Longinelli, A. 1984. Oxygen isotopes in mammal bone phosphate - a new tool for paleohydrological and paleoclimatological research. - Geochimica et Cosmochimica Acta, 48: 2, 385-390.

Lumiste, M. 1971. Pühavaimu kirik. Tallinn.

Luz, B. \& Kolodny, Y. 1985. Oxygen isotope variations in phosphate of biogenic apatites, 4. Mammal teeth and bones. - Earth and Planetary Science Letters, 75: 1, 29-36.

Mäeväli, S. 1986. Architectural and Art Monuments in Tallinn. Tallinn.

Malve, M., Kadakas, V., Kiudsoo, M. \& Tiidu, E. 2014. Archaeological studies in the church and churchyard of Kose. - AVE, 2013, 119-132.

Mänd, A. 2005. Urban Carnival: Festive Culture in the Hanseatic Cities of the Eastern Baltic, 1350-1550. (Medieval Texts and Cultures of Northern Europe, 8.) Turnhout.

Mariotti, A. 1983. Atmospheric nitrogen is a reliable standard for natural N-15 abundance measurements. - Nature, 303: 5919, 685-687.

Mark, K. 1962. Kaberla kalmistu antropoloogiline aines. - Muistsed kalmed ja aarded. Ed. H. Moora. (Arheoloogiline kogumik, II.) Eesti NSV Teaduste Akadeemia Ajaloo Instituut, Tallinn, 169-181. 
Müldner, G. \& Richards, M. P. 2005. Fast or feast: reconstructing diet in later medieval England by stable isotope analysis. - Journal of Archaeological Science, 32, 39-48.

Müller, G. 1891. Neununddreissig Estnische Predigten von Georg Müller aus den Jahren 1600-1606. (Verhandlungen der gelehrten Estnischen Gesellschaft zu Dorpat, 15.) Dorpat.

Naum, M. 2014. Multi-ethnicity and material exchanges in Late Medieval Tallinn. - European Journal of Archaeology, 17: 4, 656-677.

Nottbeck, E. V. \& Neumann, W. 1899. Geschichte und Kunstdenkmäler der Stadt Reval. Zweite Lieferung. Kirchliche Kunst. Die Grabsteine Revals, Reval.

Orton, D. C., Makowiecki, D., de Roo, T., Johnstone, C., Harland, J., Jonsson, L., Heinrich, D., Enghoff, I. B., Lõugas, L., van Neer, W., Ervynck, A., Hufthammer, A. K., Amundsen, C., Jones, A. K. G., Locker, A., Hamilton-Dyer, S., Pope, P., MacKenzie, B. R., Richards, M., O'Connell, T. C. \& Barrett, J. H. 2011. Stable isotope evidence for Late Medieval (14th-15th c.) origins of the eastern Baltic cod (Gadus morhua) fishery. - PLoS ONE, 6: 11, e27568.

Poage, M. A. \& Chamberlain, C. P. 2001. Empirical relationships between elevation and the stable isotope composition of precipitation and surface waters: consideration for studies of paleoelevation change. - American Journal of Science, 301, 1-15.

Pollard, A. M., Pellegrini, M. \& Lee-Thorp, J. A. 2011. Some observations on the conversion of dental enamel $\delta^{18} \mathrm{Op}$ values to $\delta^{18} \mathrm{Ow}$ to determine human mobility. - American Journal of Physical Anthropology, 145, 499-504.

Polnoye 1830. Полное собраніе законовъ Россійской имперіи съ 1649 года. Томъ XIX. 1770 1774. Санктпетербург.

Pryor, A. J. E., Stevens, R. E., O’Connell, T. C. \& Lister, J. R. 2014. Quantification and propagation of errors when converting vertebrate biomineral oxygen isotope data to temperature for palaeoclimate reconstruction. - Palaeogeography Palaeoclimatology Palaeoecology, 412, 99-107.

Raam, V. 1975. Arhitektuur 14. sajandi keskelt kuni 16. sajandi teise veerandini. Sakraalehitised, ühiskondlikud hooned ja elamud. - Eesti kunst kõige varasemast ajast kuni 19. saj. keskpaigani. Eds B. Bernstein et al. Eesti NSV Teaduste Akadeemia Ajaloo Instituut, Kunst, Tallinn, 55-71.

Reitsema, L. J., Crews, D. E. \& Polcyn, M. 2010. Preliminary evidence for medieval Polish diet from carbon and nitrogen stable isotopes. - Journal of Archaeological Science, 37, 1413-1423.

Richards, M. P. \& Hedges, R. E. M. 1999. Stable isotope evidence for similarities in the types of marine foods used by late Mesolithic humans at sites along the Atlantic coast of Europe. - Journal of Archaeological Science, 26: 6, 717-722.

Rozanski, K., Araguas-Araguas, L. \& Gonfiantini, R. 1992. Relation between long-term trends of O-18 isotope composition of precipitation and climate. - Science, 258: 5084, 981-985.

Rozanski, K., Araguas-Araguas, L. \& Gonfiantini, R. 1993. Isotope patterns in modern global precipitation. - Climate Change in Continental Records. Eds P. K. Swart et al. American Geophysical Union, Washington DC, 1-36.

Russow, E., Lõugas, L., Maldre, L., Hiie, S., Kihno, K., Luik, H., Kadakas, V., Sarv, K., Kadakas, U., Kalm, A. \& Reppo, M. 2013. Medieval and early modern suburban site in Tallinn, Tartu Road. 1: Artefacts and ecofacts. - AVE, 2012, 149-170.

Schoeninger, M. J. \& DeNiro, M. J. 1984. Nitrogen and carbon isotopic composition of bone collagen from marine and terrestrial animals. - Geochimica et Cosmochimica Acta, 48, 625-639.

Selart, A. 2009a. Orthodox churches in Medieval Livonia. - The Clash of Cultures on the Medieval Baltic Frontier. Ed. A. V. Murray. Ashgate, Farnham, 273-290.

Selart, A. 2009b. Russians in Livonian towns in the thirteenth and fourteenth centuries. Segregation - Integration - Assimilation: Religious and Ethnic Groups in the Medieval Towns of Central and Eastern Europe. Eds D. Keen, B. Nagy \& K. Szende. Ashgate, Farnham, 33-50.

Selirand, J. 1962. Kaberla maa-alune kalmistu (13.-17. sajand). - Muistsed kalmed ja aarded. Ed. H. Moora. (Arheoloogiline kogumik, II.) Eesti NSV Teaduste Akadeemia Ajaloo Instituut, Tallinn, 131-160.

Selirand, J. 1974. Eestlaste matmiskombed varafeodaalsete suhete tärkamise perioodil (11.-13. sajand). Eesti Raamat, Tallinn, 75-78. 
Sillasoo, Ü. \& Hiie, S. 2007. An archaeobotanical approach to investigating food of the Hanseatic period in Estonia. - Medieval Food Traditions in Northern Europe. Ed. S. Karg. (Publications from the National Museum. Studies in Archaeology \& History, 12.) Copenhagen, 73-96.

Simpkins, W. W. 1995. Isotopic composition of precipitation in central Iowa. - Journal of Hydrology, 172, 185-207.

Smith, B. H. 1991. Standards of Human Tooth Formation and Dental Age Assessment. Advances in Dental Anthropology. Wiley-Liss, New York, 143-168.

Tieszen, L. L. \& Fagre, T. 1993. Effect of diet quality on the isotopic composition of respiratory $\mathrm{CO}_{2}$, bone collagen, bioapatite and soft tissues. - Prehistoric Human Bone: Archaeology at the Molecular Level. Eds J. B. Lambert \& G. Grupe. Springer-Verlag, Berlin, 121-155.

Tiik, L. 1957. Vana Tallinn. Ajaloolis-geograafiline käsitelu linna tekkimisest ja kujunemisest. Tartu. Candidate of Sciences thesis. Manuscript in the Library of Tartu University.

Tool-Marran, E. 1971. Tallinna dominiiklaste klooster. Tallinn.

Vaga, V. 1965. Feodaalne killustatus. Kirikud ja kloostrid. - Eesti arhitektuuri ajalugu. Ed. H. Arman. Eesti Raamat, Tallinn, 86-174.

Vogel, J. C. \& van der Merwe, N. J. 1977. Isotopic evidence for early maize cultivation in New York State. - American Antiquity, 42: 2, 238-242.

Warriner, C. \& Tuross, N. 2009. Alkaline cooking and stable isotope tissue-diet spacing in swine: archaeological implications. - Journal of Archaeological Science, 36, 1690-1697.

Yeh, H.-Y., Pluskowski, A., Kalejs, U. \& Mitchell, P. D. 2014. Intestinal parasites in a mid-14th century latrine from Riga, Latvia: fish tapeworm and the consumption of uncooked fish in the medieval eastern Baltic region. - Journal of Archaeological Science, 49, 83-98.

Yoder, C. 2012. Let them eat cake? Status-based differences in diet in medieval Denmark. - Journal of Archaeological Science, 39, 1183-1193.

\section{Emma Lightfoot, Magdalena Naum, Villu Kadakas ja Erki Russow \\ TOITUMINE, ETNILISUS JA ÜHISKONDLIK STAATUS KESKAEGSES TALLINNAS, NÄHTUNA LÄBI STABIILSETE ISOTOOPIDE ANALÜÜSI}

\section{Resümee}

Toiduvalikul on tähtis osa sotsiaalsete ja kultuuriliste väärtuste hindamisel, toidu alusel eristatakse tihti "meid" "nendest". Olukorras, kus erinevad sotsiaalsed ja etnilised rühmad elavad linnalikus keskkonnas koos, võib toit olla üheks rühmaidentiteetide eristamise abinõuks. Teisest küljest võib toiduvalik olla ühtlasi vahendiks, mis toob vastandlikud rahvarühmad kokku: immigrandid võivad oma toiduvaliku kohapealsega sarnasemaks muuta, et assimileeruda kohaliku rahvastiku hulka (või toorainete piiratud saadavuse tõttu). Samas aga võib üsna väike migrantide rühm põhjustada ulatusliku sotsiaalse ja kultuurilise muutuse, eriti kui neil on kõrge staatus. Artiklis on uuritud - rakendades individuaalse toiduvaliku hindamisel stabiilsete isotoopide analüüsi -, mil määral keskaegse Tallinna, olulise kaubanduskeskuse elanikud kasutasid toitu selgete identiteetide säilitamiseks.

Uuriti neljateist inimluustikku, mis pärinevad Tallinnast (Sulevimäe kalmistu, dominiiklaste Katariina kirik, Pühavaimu kirikuaed ja Barbara kalmistu) ning sellele lähedasest maapiirkonnast (Kaberla kalmistu). Loomaluude proovid võeti 
Tartu mnt 1 kaevamistelt. Iga indiviidi puhul rakendati luu ja hamba kollageeni, samuti hambaemaili karbonaadi uurimisel, - nende indiviidide puhul, kellel see võimalikuks osutus - ka süsiniku, lämmastiku ning hapniku stabiilse isotoobi analüüsi meetodit.

Tulemused osutavad, et kuigi kõigi analüüsitud inimindiviidide toiduvalik põhines $\mathrm{C}_{3}$-taimedel ja $\mathrm{C}_{3}$-taimi söönud loomadel, siis mõned indiviidid tarbisid ka väheses koguses $\mathrm{C}_{4}$-taimi (tõenäoliselt hirssi) või mereande. $\mathrm{C}_{4}$-taimi sõid Pühavaimu kiriku juurde maetud linnaelanikud ja üks või kaks indiviidi Sulevimäe kalmistult. Arvatakse, et imporditud hirssi tarvitas keskklass. Mereande sõid ka dominiiklaste Katariina kirikusse maetud isikud. Need indiviidid tuvastati kui migrandid, tõenäoliselt kas mungad või võõramaalastest kaupmehed. Sellised tulemused osutavad, et Tallinna elanikud kasutasid toitu oma sotsiaalse staatuse, võib-olla ka etnilise eripära hoidmisel. Vaid ühe indiviidi puhul (LTL06) tuvastati toiduvalikus elu jooksul toimunud oluline muutus: täiskasvanueas lisandusid mereannid. See võib osutada, et ta saavutas elu jooksul varasemast kõrgema sotsiaalse staatuse ja püsis edaspidi kristliku toiduvaliku juures. 